\title{
Citizenship for Real: Its Hypocrisy, Its Randomness, Its Price
}

\author{
Dimitry Kochenov
}

Peter Spiro's tactful diagnosis of the flaws in Ayelet Shachar's kickoff text to this Forum is correct: Shachar fails to convince when arguing for saving citizenship against itself. (1) She understates the hypocrisy and randomness underlying any determination of citizenship. (2) She ignores the problem of de facto statelessness, which reveals a questionable understanding of discrimination. (3) She exaggerates the importance of the political dimension of citizenship and presents the link between citizenship and political participation as unproblematic. (4) Shachar claims that the sale of EU citizenship affects other member states, but this is perfectly legitimate since there is no breach of EU law involved. (5) There are multiple ways how to acquire EU citizenship which shows why Shachar's acceptance of naturalisation as a state-mandated purification ritual fails to capture reality. Overall, Shachar's argument against the Maltese policy does not stand. If we take democracy seriously, then it should be for the Maltese alone to set the price. I thus disagree also with Magni Berton when he claims that the high price at which Malta sells EU passports is problematic.

\section{I.}

There are many stories about how selling things is bad: land is not for sale; love is not for sale; salvation is not for sale. Such proclamations make one wonder whether the purpose of ethical high points is to totally contradict reality. Hypocrisy itself is difficult to sell as an argument: land can be bought, prostitution is often legal and some of the greatest art was sponsored by those who wanted to buy salvation for themselves. To insist that citizenship is not for sale is to ensure the perpetuation of the outright randomness of its conferral as well as hypocritical and self-righteous excuses lurking behind fundamental mechanisms of exclusions. Those boasting Italian great grandparents in Paraguay, members of Polish diasporas in Australia and elsewhere, large benefactors and talented sportsmen - all these people can become Europeans, however random the rules. But the critique focuses on those countries that offer citizenship for sale in a perfectly transparent way. 
It is wrong to pretend that any other principle than outright randomness is at the core of the assignment of citizenship statuses in today's world. Once the inevitable randomness of exclusion is admitted - as Shachar did in her book on the birthright lottery ${ }^{1}$ - we need to ask what citizenship is actually about.

\section{II.}

Shachar is worried about any discrimination at the point of acquisition of citizenship. However, a strict non-discrimination approach would deprive citizenship of its main function, i.e. random exclusion of large parts of society. Crucially, both de facto and de jure aspects of exclusion must be taken into account, a point that Shachar ignores in her statement. The fact that many de jure citizens are de facto stateless, in the sense of not receiving protection by their state of origin or enjoying substantive rights to return there, is of crucial importance. Idealistic images of a citizenship of the past are based on misrepresentation of social facts, perpetuating an often repugnant status quo where plenty of people are failed by their states day after day. Thus real citizenship starts with the actual extension of rights and giving the voice to those who are already formally included: women, minorities, the poor and the weak: plentiful problems remain in this regard.

Naturalisation is but a second step which serves three functions: providing citizenship status to long-term resident immigrants, respecting and recognising citizens' family ties through special naturalisation rules for family members, and reinforcing the society with talent, money, inspiration and diversity - which translates into inviting the rich, the beautiful and the smart (sometimes these three categories overlap of course).

No confusion between different groups of applicants should arise: to ask that all follow the same path is rarely helpful. Arguing for making the rules as strict as possible for all misses the different purposes of conferring nationality in the first place. Be it sports, science, money or family, it is up to the national democratic process to determine the criteria. Crucially, there is no ethical point to be made in arguing against money when loving a citizen, expensive education, or muscular power can also do the trick. Money is no less random a criterion and this is exactly what citizenship is about. Real discrimination would be to sell a partial rather than fully fledged citizenship, as Tonga does when selling its 'Tongan Protected Person Passport', which is not recognised by many other states and does not entail a right to enter and settle in Tonga. The attractiveness of such a second class citizenship is clearly limited.

Shachar, A. (2009), The Birthright Lottery. Citizenship and Global Inequality. Cambridge, MA, Harvard University Press. 


\section{III.}

Shachar overstates the actual importance of the political dimension of citizenship. In the age of post-heroic geopolitics plenty of people naturalise or cherish the nationality they already have for entirely different reasons. Indeed, the political aspect, rather than being at the core of citizenship, regrettably becomes the scapegoat for justifying refusals to extend the status to those who already belong to the society. The idea that only the right people participate in political life is so important that you will be discriminated, threatened with deportation, exploited and humiliated in order to protect the sacred body politic. The troubling truth is that more and more people do not care about politics, as opinion polls amply testify. And those who do can be politically engaged despite not having the formal status of membership - as the German citizen Daniel Cohn-Bendit was in Paris 1968. The basic presumption of the necessary connection between citizenship and political participation should be approached critically and is hardly defensible, especially in the EU (see the earlier EUDO CITIZENSHIP Forum on national voting right for EU citizens in other member states ${ }^{2}$ ). Insisting on the political dimension misrepresents thus what citizenship is about and ruins many lives by blowing a luxury right to politics totally out of proportion for the sake of justifying random exclusion.

\section{IV.}

It is clear that, just as the passports of other micro-states, Maltese citizenship as such is of very little practical value apart from visa-free travel. All the rights it brings - to work and live in the EU, non-discrimination in the EU and diplomatic protection outside the EU (when was the last time you saw a Maltese embassy?) - are related to the EU and the EU only. Clearly, what the Maltese are selling is EU citizenship and they are quite right to do so, since Member States are fully competent in this field, as international and also European law teaches us. Rich newly-minted Maltese will satisfy all the formal requirements of the EU Citizenship Directive 2004/38, thus becoming ideal EU citizens in London and Paris.

Following the Micheletti and Rottmann decisions of the Court of Justice of the European Union, the principles of EU law should be respected - and

2 Bauböck, R., P. Cayla \& C. Seth (eds.) (2012), 'Should EU citizens living in other Member States vote there in national elections?', Robert Schuman Centre for Advanced Studies EUDO Citizenship Obervatory Working Paper 2012/32, Florence: European University Institute, available at http://cadmus.eui.eu/ handle/1814/22754. 
they are, since it is unlikely that the number of Maltese investor-citizens will represent a problem in the EU context: the scale of sales will remain small even compared with the extension of EU citizenship by other states where a connection with the state itself is unnecessary, such as turning Argentinians into Italians based on the romantic ideas of inter-generational continuity or distributing Hungarian passports in the Serbian province Voivodina. Importantly, there is nothing wrong at all with these practices which are democratic and legal and supply thus a strong argument in support of the Maltese law. Indeed, investing into your nationality is at least as random (read 'sound') as investing in a lawyer to discover your Italian heritage for the sake of claiming an Italian passport.

\section{V.}

EU citizenship provides the most vivid reminder of the radical shift in the meaning of citizenship that made it a more ethically acceptable institution. Non-discrimination on the basis of nationality - the very core of EU law provides the litmus test for what national citizenship is really about in the EU today. France is prohibited from 'loving' its own nationals more than, say, resident Estonians or Maltese. The stigmatising function of citizenship is thus deactivated: humiliation of a randomly proclaimed other is not any more an option, at least legally speaking, among EU Member States. Full belonging to a society is thus not subjected any more to an arbitrary approval, putting all the bizarre language, culture and other tests that states subject newcomers to in a very interesting perspective: the very existence of the EU disproves their validity and relevance. They consist in nothing else but purification through humiliation: the "others" language and culture is presumed as not good enough and social learning is dismissed, forcing people to waste their time by subjecting them to profoundly disturbing rituals ${ }^{3}$. The very success of EU citizenship is the strongest argument against these practices, which Shachar wants to see applied to all without questioning their effectiveness and common sense. Indeed, if a Romanian is good enough to be embraced by British society as equal, subjecting a Moldovan to any kind of tests is utterly illogical: the arguments of the protection of culture, language, etc. are simply devoid of relevance when more than half a billion EU citizens a exempted from them.

\footnotetext{
Kochenov, D. (2011), 'Mevrouw de Jong Gaat Eten: EU Citizenship and the Culture of Prejudice', Robert Schuman Centre for Advanced Studies EUDO Citizenship Observatory Working Paper 2011/06, Florence: European University Institute, available at http://cadmus.eui.eu/bitstream/handle/1814/15774/RSCAS_2011_06.corr.pdf?sequence=3.
} 
For the reasons above, I do not find Shachar's arguments convincing. Maltese democracy should be respected. Distorted dreams of the past, just as contemporary hypocrisy, are not worth defending. From a purely legal perspective, Malta's case is solid: EU law is unquestionably on its side. From a human perspective, if I could have done it, I would definitely have bought EU citizenship instead of naturalising, which I experienced as a deeply humiliating process.

Open Access This chapter is licensed under the terms of the Creative Commons Attribution 4.0 International License (http://creativecommons.org/licenses/by/4.0/), which permits use, sharing, adaptation, distribution and reproduction in any medium or format, as long as you give appropriate credit to the original author(s) and the source, provide a link to the Creative Commons license and indicate if changes were made.

The images or other third party material in this chapter are included in the chapter's Creative Commons license, unless indicated otherwise in a credit line to the material. If material is not included in the chapter's Creative Commons license and your intended use is not permitted by statutory regulation or exceeds the permitted use, you will need to obtain permission directly from the copyright holder.

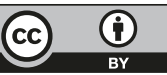

